Logos Universality Mentality Education Novelty, Section: Social Sciences

ISSN: $2284-5747$ (print), ISSN: $2284-5747$ (electronic)

Covered in: CEEOL, Index Copernicus, Ideas RePEc, EconPapers, Socionet

\title{
A PRE-TEST ON TOTAL REWARDS MODEL FOR BUSINESS CONSULTING ROMANIAN COMPANIES
}

Elena-Sabina HODOR

Logos Universality Mentality Education Novelty, Section:

Social Sciences, IV (1), 123-131

The online version of this article can be found at:

http://lumenjournals.com/social-sciences/

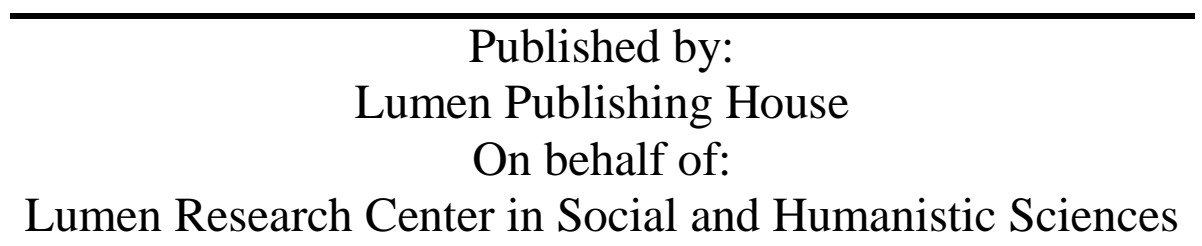




\title{
A Pre-Test on Total Rewards Model for Business Consulting Romanian Companies
}

\section{Elena-Sabina HODOR ${ }^{1}$}

\begin{abstract}
The purpose of this article it is to pre-test a methodology adapted from a study made in United States of America between January 2006 and May 2009. In order to check the applicability of the adapted instrument, there were undertake two stages. The first one was in April 2014 and included the verifying of the items from the questionnaires, and the second one was in December 2014 and involved the effective pre-test of the improved methodology from the previous step. The main aspects displayed in this paper are: the Cronbach's Alpha coefficient for the independent variables, dependent variables and for the entire instrument, and the preferred rewards by potential employees and workers for/ from Business Consulting Romanian Companies. Finally, there are concluded some improvements that can be implemented in the next period of the research.
\end{abstract}

\section{Keywords:}

Total reward, Business Consulting Romanian Industry, Cronbach's Alpha, preferred rewards.

${ }^{1}$ PhD Fellow, SOP HRD/159/1.5/133675 Project, Romanian Academy Iasi Branch, University Alexandru Ioan-Cuza, Iasi, Romania, hodorsabina@yahoo.com.

Hodor, E-S. (2015). A Pre-Test on Total Rewards Model for Business Consulting Romanian Companies. Logos Universality Mentality Education Novelty, Section: Social Sciences, IV (1), 123-131. 


\section{Introduction}

Total reward strategy includes total reward systems, while total reward systems include financial and non-financial rewards. If cuantificable benefits, contingent remuneration and salary compose the total remuneration, elements like pensions, health insurances, vacations or flexibility represent possible benefits.

On the one hand, benefits that generate costs, salary and contingent compensation are financially measurable. On the other hand, the non-financial rewards are not directly valued in cash. However, considering the reward strategy, both type of rewards (financial and nonfinancial) and benefits are part of the total rewards given to employees.

\section{Methodology}

The idea of the research starts from a study conducted in the United States of America- "The Relative Influence of Total Rewards Elements on Attraction, Motivation and Retention" (Boswell, Cook, Horner, Payne \& Shaub, 2011, pp. 1- 45) started in January 2006 and completed in May 2009. In order to use this study, this article is pretesting the previous research's methodology adapted to the intercultural characteristics of the employees and potential employees from/ for Business Consulting Romanian Companies.

The purpose of this paper it is to obtain a global view of the Cronbach's Alpha for the used instrument and to get a top regarding the preferred rewards of the subjects.

The survey it is a reduced form of a larger research, and the results presented at this point are used in order to improve the next steps.

The sample has two categories of respondents:

Potential employees for business consulting companies. These respondents are actually students interested in a career in business consultancy area. They are from Alexandru Ioan-Cuza University of Iaşi from different specializations: accounting, finance, management, marketing, statistics, and others. Many of them have never worked, or worked a little, and not necessarily in their field of study.

Employees from business consulting domain from Iaşi. This type of respondents are very important, giving consistent responses and clear answers from effective field of labor. 
Overall, $51,25 \%$ of the respondents $(n=80)$ have the age between 20 and 23 years old, 58,75\% are females and $41,25 \%$ are males and $73,75 \%$ are unmarried. $31,25 \%$ have more than 37 months of working experience (not necessarily in business consulting), while $16,25 \%$ have never worked. It is expected from the sample to bring interesting perceptions in what concerns opinions regarding the most important rewards that attract and/ or maintain human resources in organizations.

The survey uses as a data collection tool- a questionnaire adapted from WorldatWork Organization. Compared to the study made in United States of America, in Romania, some of the questions from the questionnaires are labeled as being "sensitive data". Therefore, the original instrument has been translated and also adapted to the local area, and last but not least- adjusted to comfortable types of questions.

However, the variables pursued in the data analysis process are on two levels: for the potential employees and for workers:

First of all, there are two main constructs: the total reward strategy (in the recruitment process)- for students preferences analysis and the total reward strategy (after employment)- for employees options review. Second of all, every construct it is explained by multiple variables: remuneration, benefits, work-life balance, professional development and career opportunities, performance and recognition of merits. Each of these variables it is considered for potential employees and employees as well. Further, there are taken into account some elements that can elucidate the respondent's choices: knowledge regarding the Business Consulting Industry, extraversion, materialism, striving for achievements.

In what concerns the aggregation of the items of the questionnaire, were given an equal proportion for each sub item that takes part in shaping the variables and the constructs considered.

In the table below it is illustrated general information about the collection of data: 
Table 1. Data collection

\begin{tabular}{|l|l|l|l|}
\hline \multicolumn{1}{|c|}{ Period } & \multicolumn{1}{|c|}{$\begin{array}{c}\text { General } \\
\text { objective }\end{array}$} & \multicolumn{1}{|c|}{ Sample } & \multicolumn{1}{c|}{ Results } \\
\hline \multirow{2}{*}{$\begin{array}{l}\text { To obtain an } \\
\text { adapted and } \\
2014\end{array}$} & $\begin{array}{l}\text { validated } \\
\text { instrument } \\
\text { for a larger } \\
\text { research }\end{array}$ & $\begin{array}{l}\text { University Alexandru Ioan- } \\
\text { Cuza Iasi and 40 employees } \\
\text { from Business Consulting } \\
\text { Industry from Iasi })\end{array}$ & $\begin{array}{l}\text { A rewards top and the } \\
\text { validated instrument }\end{array}$ \\
\hline
\end{tabular}

The questionnaires were collected in December 2014 via email and also in university and in the working places of the respondents. Where was necessary were clarified some concepts used in the instrument. While at the potential workers most of the misunderstood notions came up as a result of lack of knowledge in what concerns possible rewards offered by companies, employees reported rewards or benefits that have never heard about. However, after collecting data it was concluded that knowledge in total rewards comes with the working experience of the respondents.

\section{Research results}

\subsection{The Cronbach's alpha coefficient for reliability}

The first objective of this paper it is to test the intern consistency of the items from the questionnaire using the Cronbach's alpha coefficient. In order to obtain this indicator, it was made an analysis in the following manner: first it was calculated Cronbach's alpha for the variables, then for the constructs and finally it was tested overall the internal consistency of the questionnaire, considering the 115 items from which it is composed.

Below we have the results for this coefficient:

Hodor, E-S. (2015). A Pre-Test on Total Rewards Model for Business Consulting Romanian Companies. Logos Universality Mentality Education Novelty, Section: Social Sciences, IV (1), 123-131. 
Table 2. The aggregation of the items and Cronbach's alpha coefficient

\begin{tabular}{|c|c|c|c|c|}
\hline Construct/ Variable & $\begin{array}{l}\text { Number of } \\
\text { sub items }\end{array}$ & $\begin{array}{r}\text { Cron } \\
\text { al }\end{array}$ & $\begin{array}{l}\text { ch's } \\
\text { a }\end{array}$ & $\begin{array}{c}\text { Overall } \\
\text { Cronbach's } \\
\text { alpha }\end{array}$ \\
\hline $\begin{array}{l}\text { Variable- knowledge of business } \\
\text { consulting industry }\end{array}$ & 6 & 0,806 & - & \multirow{16}{*}{$\begin{array}{l}0,644 \text { (for a } \\
\text { total of } 115 \\
\text { sub items) }\end{array}$} \\
\hline Construct- extraversion & 20 & 0,076 & - & \\
\hline Construct- materialism & 6 & 0,089 & - & \\
\hline $\begin{array}{lll}\begin{array}{l}\text { Construct- } \\
\text { achievements }\end{array} & \text { striving } & \text { for } \\
\end{array}$ & 10 & 0,193 & - & \\
\hline $\begin{array}{l}\text { Construct- total reward strategy } \\
\text { (in the recruitment process): }\end{array}$ & 27 & 0,748 & $\begin{array}{l}0,7 \\
07\end{array}$ & \\
\hline Variable- compensation & 5 & 0,479 & - & \\
\hline Variable- benefits & 12 & 0,623 & - & \\
\hline Variable- work- life balance & 3 & 0,265 & - & \\
\hline $\begin{array}{l}\text { Variable- development and career } \\
\text { opportunities }\end{array}$ & 4 & 0,497 & - & \\
\hline $\begin{array}{l}\text { Variable- performance and } \\
\text { recognition of merits }\end{array}$ & 3 & 0,185 & - & \\
\hline $\begin{array}{l}\text { Construct- total reward strategy } \\
\text { (after employment) }\end{array}$ & 27 & 0,726 & $\begin{array}{l}0,6 \\
72\end{array}$ & \\
\hline Variable- compensation & 5 & 0,573 & - & \\
\hline Variable- benefits & 12 & 0,605 & - & \\
\hline Variable- work- life balance & 3 & 0,265 & - & \\
\hline $\begin{array}{l}\text { Variable- development and career } \\
\text { opportunities }\end{array}$ & 4 & 0,358 & - & \\
\hline $\begin{array}{l}\text { Variable- performance and } \\
\text { recognition of merits }\end{array}$ & 3 & 0,293 & - & \\
\hline
\end{tabular}

Usually, Cronbach's alpha coefficient has the accepted limit for the internal consistency of the items more than 0,600. Overall, the questionnaire obtained a normal value for the loyalty coefficient: 0,644 reflected through a total of 115 sub items.

The conclusion after analyzing the results it is that the more subitems has a variable or a construct, the better results will be obtained for the value of the internal consistency coefficient and vice versa. 


\subsection{The top of the preferred rewards}

Respondents were asked to pick the most important rewards that would like to be rewarded within a job from Business Consulting Industry. Moreover, they have given marks from 1 (the less important) from 5 (the more important) to the selected preferences.

The results are in the following figure:

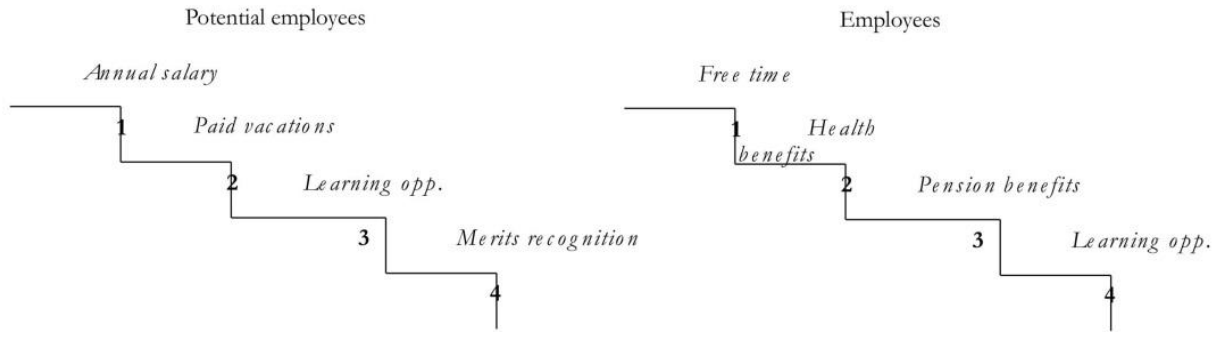

Fig. 1 - Preferred rewards for potential employees and workers for/ from Business Consulting Industry

It seems that students put accent on the annual salary, and employees want more free time (with or without pay). A possible explanation for this difference could be the fact that the students which start to be active from the professional point of view want to became financially independents right from the start, while the respondents already employed need extra free time to spent more time with their family or perhaps for other personal matters such as: doing sports, spending time with friends, time for hobbies, relaxation, and so on.

On the second place in the top of total rewards for the potential employees are the paid vacations. Employees opt for health benefits. If students want to get relax immediate, on short term, employees want to be assured that they have multiple options for the health benefits, having a long term orientation. Obviously, the differences registered between the respondents for this level come as the working experience increases. Employees are looking for such rewards with a superior degree of realism.

Learning opportunities are present in both rankings. The concept of lifelong learning has started to be agreed more and more 
among people in the workforce and even by those who want to get employed.

Another difference regarding the two previous tops is that potential employees want merit recognitions and employees think they need retirement benefits. And now comes the question: how much working experience have the potential workers that allow them to ask for merit recognition? Is that a general characteristic for the next generations? It is understandable that the workers stability may be maintained by awarding them with pension plans. The job security and certainly future incomes represent a great need for them. Anyway, pension plans are related to the private area, and not to the compulsory monthly contributions required by law.

\section{Further research}

The results represent a starting point for developing total rewards models in Business Consulting Companies. However, a logical step-by-step route for developing a total rewards model it is the next one:

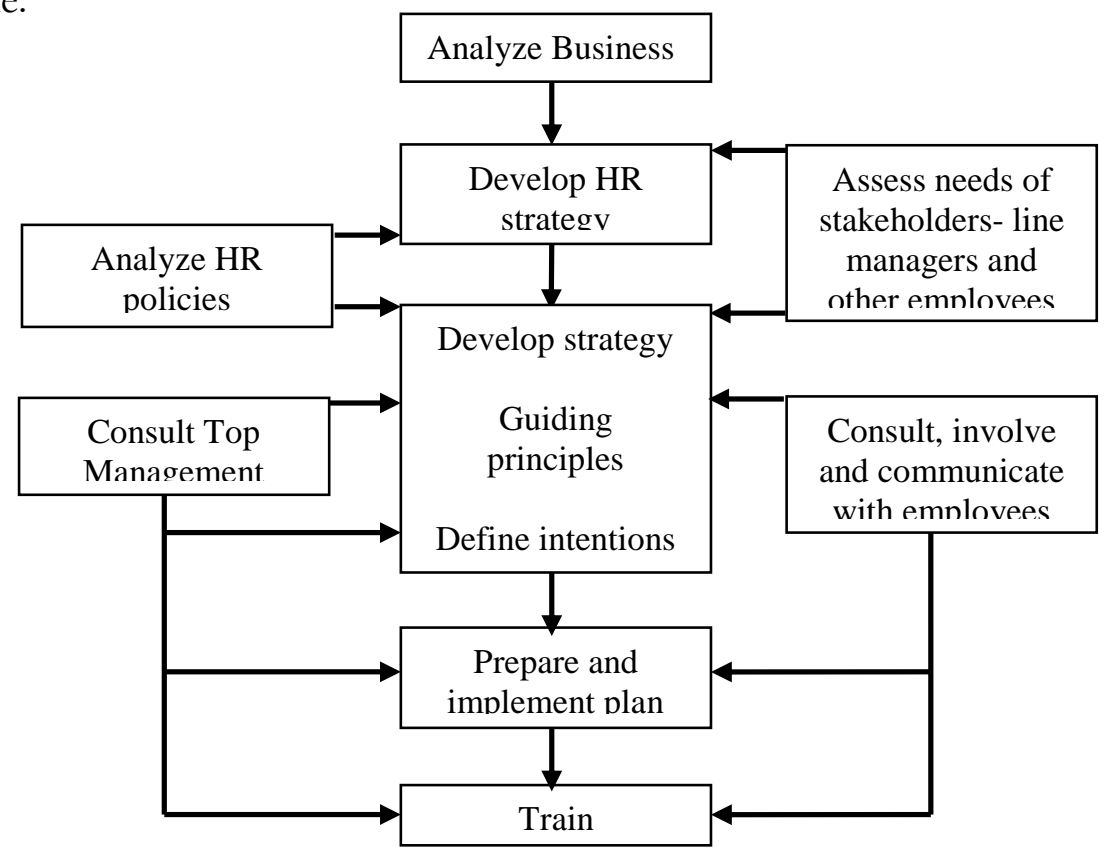

Fig. 2 - The development of reward strategy process (Armstrong \& Murlis, 2007, p. 40) 
The figure illustrates an ideal that in practice is quite absent. In reality, firms usually adjust their own rewards strategies depending on the company's general strategy. But the overall strategy depends on two types of factors: the internal factors, and the external ones.

In theory, the designing of a model starts from analyzing the business activity: field of activity, number of employees, financial stability in the recent years, risk factors, available resources and many other "key elements" for the current activity. The next step it is to create the human resource management strategy, which has three main aims: to attract, to maintain and to motivate employees on long term. Subsequently, in accordance with the overall strategy of the organization, it is prepared and implemented a "plan of attack" for allocated rewards. Finally, the process ends with the training of the employees from the human resources department on the "awarding program". During this wide process, there are involved on the one hand- employees, and on the other hand- managers and workers from human resources department from the organizations. The process it is natural and involves all the actors that "respond for the good of the company".

The logic of creating such models is that once assimilated by the company, the using of such instruments can bring improvements in employee's productivity and/or in quality of work as well. Thereby, there are expected increases in profitability and workforce stability.

\section{Conclusions}

The literature reveals that rewards are made up of: salary, benefits, learning and development, working environment elements. Both categories- remuneration and benefits can be financial (tangible) or non-financial (intangible). As a remark, financial benefits can be or not directly dependent on the remuneration paid.

From the two tops of reward obtained it results that on long term, employees need financial and non-financial benefits (either direct or indirect) in order to to be maintained into their organizations and valuable candidates can be easily attracted by offering them a package of rewars that contain especially financial direct rewards. 


\section{Acknowledgement}

This paper is supported by the Sectorial Operational Programme Human Resources Development (SOP HRD), financed from the European Social Fund and by the Romanian Government under the contract number POSDRU/159/1.5/133675.

\section{References}

Boswell, Wendy R., Cook, Allison L., Horner, Margaret T., Payne, Stephanie C. \& Shaub Michael K. (2011). The relative influence of Total Rewards Elements on Attraction, Motivation and Retention, WorldatWork Journal, 20(1), 1-45.

Armstrong, Michael, Murlis, Helen (2007). Reward management (5rd ed.). London: Kogan Page.

\section{Biodata}

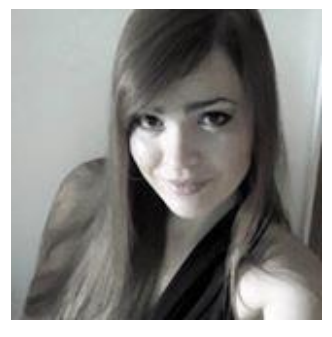

Affiliation: Romanian Academy Iasi Branch, University Alexandru Ioan-Cuza, Iasi, Romania Email address: hodorsabina@yahoo.com

Hodor Elena-Sabina is currently student in the doctoral program (second year) at the Doctoral School of Economics and Business Administration (SDEAA)- Management, Alexandru Ioan- Cuza University, Iaşi, Romania, under the guidance of the Director of the Doctoral School, Prof. PhD. Adriana Prodan. Both of the researches - undergraduate thesis and dissertation thesis were in Human Resource Management, and now the research area is Total Rewards Models in Business Consulting Romanian Companies.

She is also a student in the second year at Faculty of Law, Alexandru Ioan- Cuza University, Iaşi, Romania, and Associate PhD at Faculty of Economics and Business Administration, Alexandru Ioan Cuza University, Iaşi, Romania- teaching discipline "Management" for the $2^{\text {nd }}$ year, undergraduate.

Hodor, E-S. (2015). A Pre-Test on Total Rewards Model for Business Consulting Romanian Companies. Logos Universality Mentality Education Novelty, Section: Social Sciences, IV (1), 123-131. 